\title{
"The world too much with us? Rot!": William Carlos Williams and the Ethics of Literary Perception
}

\section{Ciarán O’Rourke}

Trinity College Dublin

\begin{abstract}
This paper examines the poetics of perception and the accompanying moral commitments of William Carlos Williams's poetry, paying attention in particular to the visual ethos of his work. If in his early years Williams conceptualized the poet's function as "lifting to the imagination those things which lie under the direct scrutiny of the senses." One of the chief arguments here is that this emphasis be understood as an expansive and ethically implicating one, rather than in creatively circumscribing terms. "Such war, as the arts live and breathe by," Williams asserts in 1944, "is continuous." After establishing the ethical basis for Williams's poetics, this paper assesses the perceptual politics of his work of the 1940s specifically, and in a number of literary and historical contexts, including: his revisionary engagement with William Wordsworth and the Romantic tradition; his infamous poetic "exultation" at the bombing of London in 1941 and his elegy for President Franklin Delano Roosevelt; and his politically complex and often incendiary poems of social observation in these years. As such, this article both reveals and interrogates the sometimes contradictory ethical engagements and creative procedures that define Williams's work in a period of profound political crisis.
\end{abstract}

Keywords: Modernism, poetry, politics, Second World War, New Deal

\section{"I have eyes / that are made to see": Making Sense of Williams's Poetics \\ This article examines the poetics of perception and the accompanying moral commitments of William Carlos Williams's work in the 1940s. If in}


his early years Williams could conceptualize the poet's function as that of "lifting to the imagination those things which lie under the direct scrutiny of the senses" (Selected Essays, 11), one of the principal assertions here is that, as critics, we must understand this emphasis as an expansive and ethically implicating one, rather than in creatively circumscribing terms. "Every work of art is a microcosm of the world", Williams declared, "[e] very fiber of [the artist's] poem is to him a total of his world" (A Recognizable Image , 228). For Williams, such an understanding of aesthetic purpose demands both a sensuous responsiveness to material experience and an exploratory understanding of social relationships - one that extends beyond the poet's field of perceptions per se. It is partly with this dual tendency in mind, indeed, that Stephen Matterson can interpret Williams's "developing poetic" as being "grounded in an ethical dimension", his poems positing - in their language, formal make-up, and outlook - "a claim to equality of observing mind and observed things" (History of Modernist Poetry, 35051), while Ian Copestake, similarly, identifies Williams's praxis-based affirmation of "inclusivity" and "[o]penness" as one of the "ethical roots of his poetry"(Ethics,152).

If this paper sometimes calls into question the sufficiency of Williams's ethical commitments, and unveils the problematic presumptions that undergird Williams's vivid American imaginary, the point is nonetheless instructive: that the almost phenomenological grace Williams bestows on his poetic subjects and settings is both sociological and aesthetic, a symptom of his deeper understanding of poetry as a means of ethical endeavor. Art, Williams writes, "can be made of anything, provided it be seen, smelt, touched, apprehended, and understood to be what it is - the flesh of a constantly repeated permanence" (Selected Letters, 130). Yet the politics of this condition are such, for him, that the poem becomes "a social instrument", enabling what he terms "the lifting of an environment to expression" ( $S L$, 286). This paper explores such creative apothegms in action, examining the complex politics of perception and understanding that Williams evolves in his poetry, with a broad focus on his work produced in the 1940s.

Writing to literary columnist Harvey Breit at the beginning of that decade, Williams tellingly indicates his own unsettled anticipation of the years to come. "Whether or not", Williams muses, 
the fiery demon that possesses the world is going to destroy us or give us a new birth I cannot say. All we know is that only a few years ago we were too smug in our beliefs touching the ultimate triumph of man's coming humanity to man.... We were too glib, too sanguine, too languid in what we thought and said... too doctrinaire in our praise and service. $(S L, 189)$

The ensuing years constitute a period of profound political and creative unease for both Williams and his world - and one in which his sense of poetic engagement consequently develops in a number of critically resonant ways. In The Wedge (1944), we find Williams arguing that his poems are "the war, or a part of it", forming "merely a different sector of the field" (Collected Poems: Volume 2, 53). One of the most consistent themes of Williams's writing in the 1940s in fact centers on the value (as well as the potential inadequacy) of art as a means of addressing the struggles and material devastations in which ordinary people across the globe are variously engulfed. "Is Germany's bestiality", Williams queries in "Mirrors", "any more than a reflection of the world's / evil?", suggesting of the photographic "negative" of fascism and its supporters that the "world is at its worst the / positive to these foils, / imaged there as on the eyes of a fly" (CP2, 139-40). Williams posits a shared complicity in the events (and atrocities) of contemporary history, but does so, significantly, by refracting this perception through the double lens of scientific modernity (the "infra-red /searching" of "a landscape obscured / to the unaided eye") and primal nature (the morally inscrutable "eyes of a fly") $(C P 2,140)$. The ethical imperatives to which Williams responds are thus both complicated and laid bare by the poem's own metaphors of insight - the "bestiality" of the times at once clarified and made strange by its aesthetic of lurid, ludic objectivity.

Over the course of his poetic career Williams's perennial emphasis on the need to apprehend ordinarily disregarded things afresh - wandering "among the side streets" of "the sick" (Collected Poems: Volume 1,456) to find that they "astonish" him "beyond words!" $(C P 1,43)$ - manifests an increasingly nuanced attention to the processes and problematics of poetic perception itself. So in "3 A.M. The Girl With the Honey Colored Hair", first published in 1949, Williams stages in microcosm what might be termed the visual culture of daily life - the physical and social forms of perception, interaction, and mutual revelation that frame the girl's entrance into a hospital room. "Everyone looked", Williams writes in the poem, "and, passing, revealed / himself" $(C P 2,221)$. In like fashion, the meticulous cataloguing of char- 
acters which follows - of "the haggard drunk / holding onto the backs of the seats" and "the savage-looking female wearing / a picture hat" - serves to highlight Williams's own spectatorial role and process in the scene described, before the girl herself "turned frightened to address / me, pitifully alone" $(C P 2,222)$. For Williams, to make life visible is as much an act of self-revelation and sensuous self-intimacy as it is of outward description.

This is a defining tendency throughout Williams's post-war work, which often invests such questions of literary (self-)portraiture with a distinctly ethical charge. Williams's 1954 meditation on Michelangelo's series of slave-themed sculptures, entitled "The Yellow Flower", may service a relevant example. "I have eyes", Williams writes in the poem,

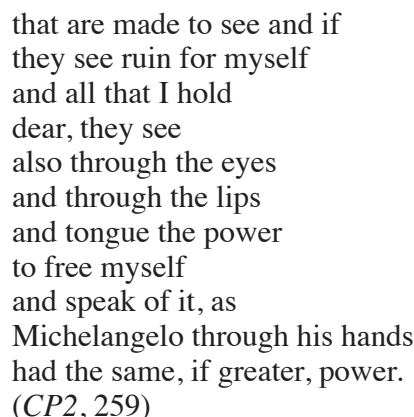

Art, Williams suggests - and whether understood as sculpture or poetry - is at least partly an extension of the individual's physical and sensory capacities, and in fact depends for its realization on the enhanced application of these. Williams's famous adage, "Say it! No ideas but in things" (Paterson, 9), advances a similar perspective, consciously associating verbal articulacy, mental imagination, and materiality itself as interlinked elements of the poetic process. And yet, if there is a universality to be had in an art that draws its "power" from the "eyes", "lips / and tongue", Williams is also very much aware of the potential insularity of a creativity based on the individual's sensate powers or self-perceptions alone. The ability to feel, perceive, and interact with the material world may provide a common ground of poetic meaning, which theoretically all people can access, but such capacities also point to the forms of violence felt disproportionately by some over others. So, "The Yellow Flower" continues: 
Which leaves, to account for,

the tortured bodies of

the slaves themselves

and the tortured body of my flower

$(\mathrm{CP} 2,259)$

An acknowledgement of the correlation between art and reality, between the poet and the world he describes, must encompass the "tortured bodies" which co-exist with the artist in that reality - inhabiting, indeed, the same scope of sensory perception and potential empathy in which the poem takes shape. Similarly, poetic symbols such as the "flower" will always be "tortured" by dint of the violence on which (what he calls in the late poem, "An Exercise) "this // modern age" rests $(C P 2,427)$, and which art itself partly expresses.

For Williams, crucially, to bring these elements to creative realization in poetry is to register and respond to the conflicts of modernity itself - to choose the "good" and the rational, in place of those doctrines of dehumanization by which "the Catholic church" historically, for instance, and "Stalin and all his kind" in the contemporary world have asserted dominance $(C P 2,477)$. The ethical outlook of Williams's work is attuned as much to the crises of contemporary history as to questions of literary form; its compelling power, indeed, arguably resides in its conscious inter-connection of each to each, as 1946's "Choral: The Pink Church" may suggest. Calling on the "aberrant, / drunks, prostitutes, / Surrealists" of ages past "to bear witness", Williams conjures a chorus of the dispossessed, a vision ("transparent to the light") of creative commonality through time, "if the image hold" $(C P 2,177)$ :

\author{
[...] beyond them all whine \\ the slaughtered, the famished \\ and the lonely - \\ the holy church of \\ their minds singing madly \\ in tune, its stones \\ sibilant and roaring - \\ $(C P 2,179-80)$
}

In its transcendent numeration and celebration of social, sexual, and poetic avant-gardes, "Choral: The Pink Church" stands as an uncompromising re- 
tort to the atmosphere of creative censure and political moralism of its era and in this respect prefigures Allen Ginsberg's Howl (1955). If "this nightmare world explodes", Ginsberg writes of postwar American society, "it will all have been a dream with latencies, symbols, daydreams clairvoyant, and tiny perfect poems... full of intuition and unconscious prophecy" (Deliberate Prose, 217-18) - an eerily familiar dreamscape that "Choral: The Pink Church" intuits in its own mode of vatic protest. To "scant the truth / of the light itself", Williams similarly projects a decade later, the "Ginsberg / of Kaddish falls apart / violently to a peal of laughter" $(C P 2,377)$.

Significantly, in "Choral" Williams also takes the opportunity to articulate his disdain for contemporary academic and literary standards - relating these to the culture of engineered elitism he discerns in contemporary American society, and to which he is certain "Poe, Whitman, Baudelaire... the saints / of this calendar" would be opposed:

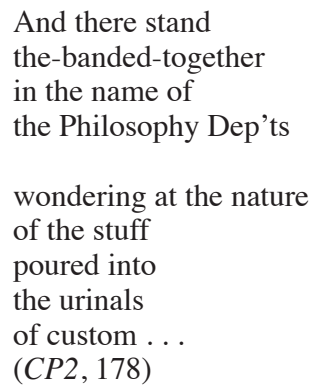

Williams's seeming effort to debase the cultural customs of his day reflects one of the poem's deeper concerns. For in situating the cause of the "aberrant" artists - the proto-modernists of ages past - firmly on the side of "the slaughtered, the famished / and the lonely", Williams is making an argument for art's purpose in the world: to face the degradations and injustices of its time clearly, opposing these to the custodians of a culture who are seemingly (and perhaps deliberately) oblivious to them:

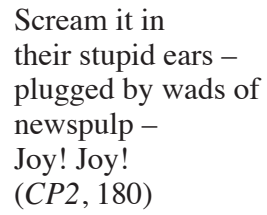


If Seth Forrest can argue that"[the] alertness of the listening mind is the key to understanding the innovations that have etched [Williams's] place in the canon of poetic modernism" (66), it is worth noting how the act of creative listening implied in the image here attempts to collapse those discursive fields (or, literal "wads of / newspulp") that mediate between experience and understanding: "Scream it in / [...] their stupid ears."

The tension between what the senses can perceive and what the "newspulp" and poetic conventions of the day block from consideration in fact forms the creative ground from which much of Williams's work in this 1940s particularly springs. The poem, "The Mind's Games", may serve as a case in point. It begins:

\begin{abstract}
If a man can say of his life or any moment of his life, There is nothing more to be desired! his state becomes like that told in the famous double sonnet - but without the sonnet's restrictions. Let him go look at the river flowing or the bank of late flowers, there will be one small fly still among the petals in whose gauzy wings raised above its back a rainbow shines. The world to him is radiant and even the fact of poverty is wholly without despair. $(C P 2,159-60)$
\end{abstract}

As Williams makes plain, the piece is both a reflection on the world and a revisionary engagement with poetic tradition per se. This is a poem that scrutinizes the way in which poetry frames experience, and the forms it adopts to do so - the "restrictions" of the sonnet thus relating, for Williams, to the limitations of the worldview that conventional poetic modes propose. To "look / at the river flowing" or to observe a "small fly" with wings in which "a rainbow" shines may indeed provide a counterweight to "despair", and a sense of wonder at the radiance of natural life - as advanced throughout the Romantic tradition $(C P 2,159-60)$. The poem, however, also mounts a literary-critical retort to such presumptions by introducing "the fact / of poverty" into the picture of "radiant" self-satisfaction conveyed (CP2, 159-60) - a partial echo, perhaps, of Williams's early insistence that, in art, there can be "no ideas beside the facts" (CP I 267). 
Williams goes on to develop this thematic stress into something of a critical crescendo. "So it seems", Williams writes of the pastoral sentiment he has just expressed,

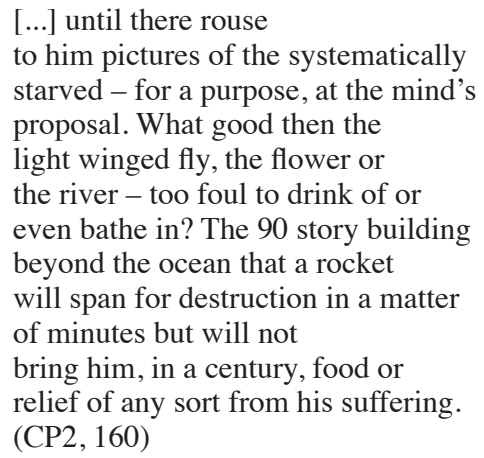

The poem eviscerates one of the key tropes of canonical Romantic literature: that the contemplative mind may find in the natural world a solace to hold against despondency and pain, repairing what Wordsworth prescribes as a kind of gash in modernity's collective psyche, whereby "Little we see in nature that is ours; / We have given our hearts away, a sordid boon!" "So might I", Wordsworth writes, "standing on this pleasant lea, / Have glimpses that would make me less forlorn" (Wordsworth Reader, 237). Williams, by contrast, posits such consolation as itself a kind of complicity, implying that the supposed pastoral comforts of poetry are contradicted by man's material relationship to the world, and indeed by "the mind's" own appetite for destruction and self-delusion. On closer inspection, Williams observes, "the river flowing" is "too foul to drink of or / even bathe in", while the apprehension of "poverty [...] without despair" is only possible by way of ignoring the "systematically / starved - for a purpose" of the human mind's devising $(C P 2,160)$.

Poetic truth, Williams asserts, is a thoroughly ideological category. Openly referencing William Wordsworth's sonnet, "The World is Too Much With Us", the poem concludes:

The world too much with us? Rot! the world is not half enough with us the rot of a potato with 
a healthy skin, a rot that is never revealed till we are about to eat - and it revolts us. Beauty?

Beauty should make us paupers, should blind us, rob us - for it does not feed the sufferer but makes his suffering a fly-blown putrescence and ourselves decay - unless the ecstasy be general.

$(C P 2,160)$

Williams's "fly [with] gauzy wings" through which "a rainbow shines" has become an incubus of "putrescence" - the poem's symbolism refigured as being itself a cause and symptom of that very misery from which the meditative mind purports to be escaping. "Beauty", Williams declares, is only one of the mind's games designed to disregard (and even to perpetuate) human "suffering" - unless, that is, the transcendence attained is available to all: "Beauty should make us paupers [...] unless the ecstacy be general" $(C P 2,160)$.

The poem is a tour de force in ethical critique and aesthetic self-scrutiny - evincing the importance accorded to material consciousness in Williams's poetic thought and practice. For Williams, if poetry depends on an intensified awareness of one's own physical and perceptive experience, it also thereby gestures to the material suffering to which such experience amounts for many. Lacking this, Williams suggests, the poem fails as a creative enterprise, being bound as it is to "rot" and "decay" $(C P 2,160)$.

Importantly, the atrocity Williams holds up as emblematic of mankind's moral and aesthetic corruption in the poem appears to be the Irish potato famine - "the rot of a potato with / a healthy skin" conjuring "pictures of the systematically starved" $(C P 2,160)$. If this is the case, Williams's reference is very much in step with his distrust of British imperialism and hierarchy, specifically - a distrust which his reference to William Wordsworth also relays in cultural terms, rendering "language" itself, as Elin Käck suggests, "a central site of struggle" (89). For as Alec Marsh memorably observes: "[t]he resentment of the post-colonial writer is everywhere in Williams... when [he] speaks, as he frequently does, of 'setting words free' he means to free them from the dead hand of the English colonizer" (Cambridge Companion, 84). Certainly, Williams's disdain for the imperial history and what he views as the ingrained social inequities of British life is in evidence throughout his work in the period in which "The Mind's Games" is written 
- a factor that highlights central questions (and contradictions) concerning his critical outlook in general, as the next segment of this discussion shows.

\section{"All mankind weeping": Williams and the Politics of Mourning}

As Marsh implies above, Williams's bias against England's empire and monarchy (not to mention, English poetry) is often as rhetorically bombastic as it is creatively directive - and as such serves both to accentuate and revise the ethical valencies that inform his poetic practice. For Williams, of course, international politics is an intensely personal affair. Expressing his contempt for "that murderous gang [Pound] says he's for" (referring to the fascist parties of Hitler and Mussolini in Europe), Williams for instance confesses to James Laughlin in 1939 that he "can hardly bear the thought of shaking hands with the guy if he does show up here - I'd say the same to my own father under the circumstances ", adding later:

The logicallity [sic] of fascist rationalizations is soon going to kill him. You can't argue away wanton slaughter of innocent women and children by the neo-scholasticism of a controlled economy program. (JL/WCW, 45-49)

The episode offers a telling insight into the importance Williams accords to questions of political commitment and commentary in his own life, while also serving to revise critic Glen MacLeod's contention that the "chief disagreement between Pound and Williams [...] was over whether the revolutionary modernist movement was to be fundamentally local and American or cosmopolitan and European" (Cambridge Companion, 26). The latter view vastly underplays the force of Williams's disagreement with Pound in the political arena. As Williams himself will later write (with evident frustration) to Robert McAlmon, concerning Pound's imagination of a supposedly more "beautiful world":

But Jesus, what did it lead him to? To an attempt to condone Hitler, to a completely unfeeling attitude toward the Spanish rebels, to real joy at the thought of Russians slaughtered by the millions at the time of Hitler's first successes. If that's the end of his grand schemes then he's a plain dupe of his own vanity. (SL, 213) 
Such remarks, of course, cast a stark spotlight on a near-contemporaneous phase of Williams's own literary career - whereby he appears to rationalize the aerial bombing of London as an appropriate fate for British society marked, in his view, by its own history of colonial violence and exploitation. If Williams's will to make the ineffabilities of such history speakable in every sense is commendable, his apparent ease in acclimatizing to the destructive effects of modern warfare is perturbing and problematic - as detailed in the discussion below. Williams's 1941 piece, "An Exultation", begins:

England, confess your sins! Toward the poor, upon the body of my grandmother. Let the agents of destruction purify you with bombs, cleanse you of the profits of your iniquities to the last agony of relinquishment.

$(C P 2,42)$

Written in the aftermath of the German bombing campaign against London and other British industrial centres in 1940, Williams's poem celebrates the ensuing carnage as a kind of karmic retort to the long-standing social injustices of British life. In Williams's view, English society is being punished for the "profits" its ruling classes have extracted from "the poor" throughout history, and indeed for the "sins" committed "upon the body of [his] grandmother" - whose reasons for emigrating from England Williams suggests are socially conditioned. As he remarks in a footnote accompanying the poem on first publication in Partisan Review, July 1941:

My English grandmother... had been an orphan who was adopted by a 'rich' family of Godwins living in London. They brought her up. Something then happened, she always kept it a mystery, which caused her to leave them.... In any case she came to America with my father a five-year-old child... I have inherited her resentment against England, taking part with all those who have carried Empire on their shoulders and been given slums to live in for their pains. $(C P 2,452)$

"I have always hated the English ruling class", Williams continues, adding that "whatever England gets now is a just retribution" $(C P 2,452)$. In the coarseness and dogged sincerity of its anti-imperialism, the poem stands as a deliberate provocation to received views of the war in Europe - subverting patriotic identifications with Britain by exposing what Williams sees as 
the corrupt organization of British society. "Thanks!", Williams writes after the German aerial bombardment operations,

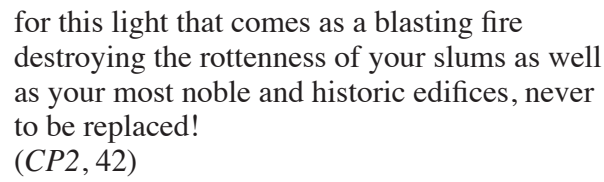

Williams's reaction to London's devastation seems to be both unnervingly detached from the human implications of the attacks and riotously enthused by the vista evoked. Such a desensitized stance on Williams's part may of course seem at odds with the ethically engaged poetics delineated above, and yet exactly the same dynamic animates an article he pens for the magazine Now in the same year (1941). It partly reads:

\footnotetext{
The doing away with the slum districts of London is an excellent thing. War has begun the demolition of the slum districts of London. But this is not an act to be credited to war as an agent but to the release of energies consequent upon war. The necessary destruction could have been better done, more economically, with less collateral waste through the agency of peace but only a violent peace dominated by revolution. The means were locked up in stupidity, war released them. $(S E, 247)$
}

Williams's conception of industrial warfare is in some ways engaging. War, Williams suggests, is merely an intensification of society's material capacities towards a common end, a destructive variant on that fundamentally creative process of change he terms "revolution" - razing existing conditions, and in this sense holding out the possibility of political regeneration and renewal. Additionally, the poem presents an understanding of the cultural life of London and the political traditions on which it rests as being mutually embedded forms of experience, with each - in Williams's view - in need of criticism and change.

In this respect, Williams's perspective is consistent with the political positions advanced throughout the edition of Partisan Review in which "An Exultation" is first published. Just as Williams's concern is to effect a radical critique of Britain's embedded infrastructures of oppression and hierarchy - rather than to deplore the immediate violence of the war itself - so Clement Greenberg and Dwight MacDonald argue in the same pages: 
[the] social system of Churchill and Roosevelt is so incompetent to plan large-scale production whether for war or peace, so lacking in appeal to the masses, that it is a weapon which is breaking in the hands of those who would turn it against Hitlerism... [the] only way this conflict can be won in the interests of mankind as a whole is by some method of warfare that will transfer the struggle from the flesh of humanity to its mind. Such a method is offered only by the cause of the socialist revolution. (272-76)

To the extent that he exposes the historical injustices and existing social hierarchies in Britain, then, Williams's obdurate celebration of their devastation is largely in keeping with the anti-capitalist and anti-imperialist analysis of the two critics here. As such, Williams may even be seen to demonstrate a commendable skepticism toward the discourses of patriotic alliance and sacrifice of his day.

The issue, of course, is that Williams's poem articulates said critique neither fully nor well. Indeed, his urge to champion the plight of "the poor" and expose the "sins" of the British Empire is fundamentally in conflict with his exultation at the "destruction" of English metropolitan centers $(C P 2,42)$. What could easily have been a persuasive articulation of antiimperialist sentiments, akin in critical terms to that of Greenberg and MacDonald, seems instead to advertise an overblown pleasure at the supposed purification of a civilian-crowded city by bombs. The moral and political complications of such positions are clearly apparent, moreover, in the poem's description of Europe's fascist nations as having - although "rotten to the core" - a "sovereignty / they cannot comprehend", as they bring the "cleansing mystery" of their bombs to bear on the British capital $(C P 2,42)$.

This stance is obviously as problematic as it is provocative, confusing the turbid implications of militarized devastation for the tangible prospect of progressive social change. Williams's urge (discussed above) to highlight the plight of "the slaughtered, the famished" $(C P 2,179)$, moreover, is qualified, if not undone entirely, in this instance by a nationalistic (even jingoistic) belief in progress by total warfare. Williams has in fact received canonical censure in exactly these terms - in the guise of Michael Heffernan's "An Exculpation". "The dear old woman was well gone by that time", Heffernan writes with accusatory aplomb, and in reference to Williams's grandmother, "but T. S. Eliot was afoot in London":

It seems you wanted him to produce a stench of human skin and hair left smoldering, because you did not like what he stood for. 
Never mind the schoolboys to be burnt as well, pensioners, postulants, pipe-shop proprietors, old damsels stitching sonnets from garden paths.

(Visiting Dr. Williams, 67)

Heffernan's antiphon is astutely judged, as Williams's footnote to the poem in Partisan Review confirms. In it, Williams expresses his ill feeling towards T. S. Eliot as a cultural figure, while advancing his own multi-faceted (if, once again, narrowly focused) understanding of English traditions. "Perhaps it should be added", Williams writes,

that my contempt for and distrust of T. S. Eliot and all he does and says comes from the feeling I have that he and others like him have allied themselves with that part of the English character which unless it is cleansed by an economic and therefore spiritual hurricane will destroy that which $\mathrm{I}$, in a way very different from theirs, profoundly love. $(C P 2,453)$

As before, Williams's “economic [and] spiritual hurricane" here may signify either the destructive power of war or the promise of a socialist-style revolution - but in either case suggests a jarringly abstract understanding of the material upheavals involved. Heffernan, once again, taps into exactly this tension in his response, imagining Williams

stretching back into your suburban easy chair to seete in spotless fury on your screened-in porch, with a sassy little Beaujolais after lunch.

I had not come to hate poets the way you did, enough to wish them broiled and their country charred, while every village screamed from blazing hell. (68)

While the royalism and Anglo-Catholicism to which T. S. Eliot professes his cultural allegiance may indeed have been used to inflict suffering on Williams's grandmother and others, (as Heffernan's response suggests) it is Williams's political and ethical shortcomings, not Eliot's, that this poem does most to illuminate.

On which note, if "An Exultation" shows Williams adopting an uncharacteristically callous attitude to human suffering for historical (and, one suspects, for aesthetic) reasons, the poem is also significant for what it tells us about Williams's grasp of domestic politics in America in the same wartime 
period. In contrast to Greenberg and MacDonald, for example, Williams offers no hint of criticism of the Roosevelt administration in either "An Exultation" or the prose statements that qualify it. Often referring to him as "the good President," indeed, Williams's support for Roosevelt throughout his tenure in office arguably signals both the nature and the limitations of Williams's political worldview, while once again clarifying the ethical impulse that undergirds his poetic work (Mariani, New World Naked, 337).

If Roosevelt is famed for overseeing a range of "New Deal" economic and social reforms in the 1930s, the effectiveness of these in challenging structures of inequality in America has been the object of much critical debate - including contemporaneously, in publications such as Partisan Review, as we have seen, and by members of Roosevelt's own administration. A decade after the stock market crash of 1929 and six years following Roosevelt's inauguration as President in 1933, Secretary of Commerce Harry Hopkins can thus be found remarking on the state of nation: "With 12 millions unemployed, we are socially bankrupt and politically unstable" (Williams, Contours of American History, 414). Roosevelt's three-term administration is of course also remembered for ignoring and even on occasion actively deepening racist divisions in American society. As David Roediger has noted, Roosevelt's legacy in the realm of racial politics may be judged not only by his executive order to incarcerate 120,000 Japanese Americans in 1942, but also by the effects of the New Deal reform program on communities already suffering racial segregation, particularly in the Southern States:

The seeds of colorblind inequality, of disunity between 'white ethnics' and workers of color, and of what Martin Luther King could call the 'tranquilizing drug of gradualism,' were present in the very foundations of the New Deal... New Deal liberalism not only failed to dismantle connections between government and white supremacy but also reforged those connections in new, modern, mass-based, and enduring forms. (How Race Survived US History, 183-84)

Despite his proximity to the left-wing and radical media of his day, Williams seems to hold no such qualms about Roosevelt's politics or legacy. As Paul Mariani notes, when hearing of the president's death, Williams rather finds himself "weeping for his lost leader," the "man," as far as he is concerned, "who had taken them through the Depression and seen them through the war" (505). 
Written in mourning for the deceased president in 1945, Williams's "Death by Radio" is as patriotically nostalgic as it is poetically hackneyed - and certainly falls short of a work such as Whitman's similarly admiring elegy for Abraham Lincoln, "When Lilacs Last in the Dooryard Bloom'd". Williams's poem reads:

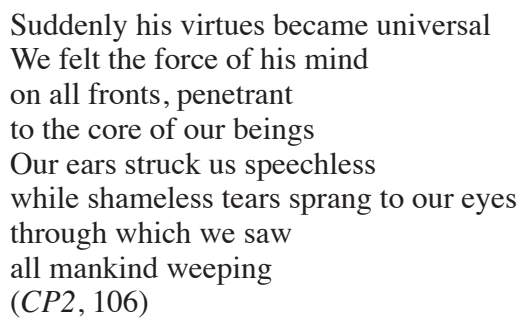

Much of the poem's phrasing is cumbersome or imaginatively flat - "his virtues became universal", "the force of his mind", "the core of our beings", and "Our ears struck us speechless" lack both descriptive freshness and imagistic sense, and do little to activate the intense understanding of Roosevelt's death which they are supposed to convey. More suggestive for critical purposes, however, is Williams's satisfaction to state, rather than persuade of, the "virtues" and significance of Roosevelt's presidency ( $C P 2$, 106). If the poem evokes images of the world in a state of tribulation - the "force" of Roosevelt resonating "on all fronts", for "all mankind", while the announcement by radio resounds deafeningly as it "[strikes] us speechless" - Williams seems to suggest that this is due less to the global conflict, than to the sadness the world should be feeling at the death of the American President. Williams, indeed, is self-avowedly "shameless" in projecting his own "tears" and political vision onto "all mankind" $(C P 2,106)$. The poem has not discovered a universal truth so much as manufactured and exported it to all the globe (by sheer patriotic insistence): that the loss of Roosevelt, along with the "virtues" of the politics he represents, is one for which humanity at large should mourn $(C P 2,106)$.

Williams's apparently abiding sense of national feeling and purpose here is clarified by a love poem from the same period, called "The United States". An exercise in political self-imagining as much as it is an expression of amorous desire, the poem begins by frankly stating the relation between America and the world that in "Death by Radio" is only implied: 
The government of your body, sweet, shall be my model for the world. There is no desire in me to rule that world or to advise it. Look how it rouses with the sun, shuts with night and sleeps fringed by the slowly turning stars...

$(C P 2,111-12)$.

The poem revels in the knowledge that love is propagandistic - a play of shifting entitlements and submissions, flatteries and possessions. As such, in exploring the analogy between the intimacies of love and geo-politics, the poem self-consciously exposes the discourses of allegiance, desire, and natural necessity on which love and patriotism alike rely. As in "Death by Radio", Williams's approach to these discourses seems to presume some degree of accession as both inevitable and proper: the poet yields his "willing services" in the knowledge (or so he contends) that neither he nor the United States desires "to rule / the world or to advise it", but merely to live in the full and "peaceful" freedoms it promises $(C P 2,111-12)$. In contrast to his work that addresses themes of British nationalism and empire, by writing in the mode of love poetry here Williams exposes, but also re-asserts the forms of affiliation on which "The United States" depends: praise, fidelity, and an apparently instinctive belief in the justice of the cause. As the final portion of this paper indicates, however, such a dynamic in Williams's work is not as always as clear-cut as it at first appears.

\section{Envisioning America's "extraordinary places, as vivid as any"}

Williams's sense of the exceptionalism of American democracy in the 1940s may be potent, but it is nonetheless tempered by his equally intense awareness of the material impoverishments that undergird American society - including during the post-New Deal era, when Roosevelt is still alive and in office. Although rarely acknowledged, such impoverishments lie at the heart and root of wartime American society Williams is concerned to engage in poetic terms. As Howard Zinn has observed:

When the New Deal was over, capitalism remained intact. The rich still controlled the nation's wealth, as well as its laws, courts, police, newspapers, churches, colleges. Enough help had been given to enough people to make Roosevelt a hero to millions, but the same 
system that had brought depression and crisis - the system of waste, of inequality, of concern for profit over human need, remained. (People's History, 403-4)

If Roosevelt remains a hero of Williams's (and primarily for the reasons Zinn outlines here), the later poetry nonetheless consistently bears testament to Zinn's claim - that the post-New Deal American society in which Williams lives and works is one based on excessive "waste", "inequality" and a neglect of basic human needs. As such, Williams's poem, "Election Day" (1941) may serve as a counterweight to the discourses of national feeling that permeate the pieces discussed in the previous segment. The poem reads:

\author{
Warm sun, quiet air \\ an old man sits \\ in the doorway of \\ a broken house - \\ boards for windows \\ plaster falling \\ from between the stones \\ and strokes the head \\ of a spotted dog \\ (CP2, 25-6)
}

The piece extends an internal tradition of Williams's work, in which the descriptive poem assumes parabolic resonance through its very literalness and individuation - or as Milton A. Cohen puts it, in which a "particular kind of political poem" takes shape by way of "closely observed details [that] reflect the time, but refuse to impose on it a trendy social message" (Cambridge Companion, 73). While Cohen is in all likelihood correct that trendiness is not Williams's main motivation in writing such a poem, he perhaps overstates his case by denying to the work its "social message", which in most cases flares beneath the surface of those details Williams selects so attentively from his environment. The "message" is manifest in the materiality of the scene, and the manner in which this is apprehended meticulously, purposefully, and with an almost aching need to record and praise. A list of similar pieces from Williams's corpus might include critically suggestive poems such as "Proletarian Portrait" and "To a Poor Old 
Woman", as well as some of the less obviously political snapshots of daily life, like "The Great Figure", or indeed "The Red Wheelbarrow". In each poem, the method forms part of the meaning, as Williams records life at its most particulate, and yet also transcends this urge, accessing the universal in the local. "Election Day" thus functions as a kind of kinetic palimpsest the gradual encroachment of social decay, the "boards for windows / plaster falling", underlying the man's own physical presence and process, as he "strokes the head" of his (possibly ill) dog $(C P 2,25-26)$.

The poem is also instructive in indicating how the universality intuited by Williams is not in all cases a philosophical or sensuous category - a sense of shared humanity based on common physical or ideational capacities. Rather, as the poem's title suggests, the mode of general experience which Williams's poem activates and gestures towards is overtly political - concerning the organization and electoral traditions of American society, as well as the forms of exclusion and affliction produced therein. The old man's "broken house" serves to reflect (if not to accuse) the greater house of American democracy, divided or otherwise as it may be - a sign once more of Williams's keen attention to the corruption and inequity on which his culture very often rests. As he puts it in another poem in this period:

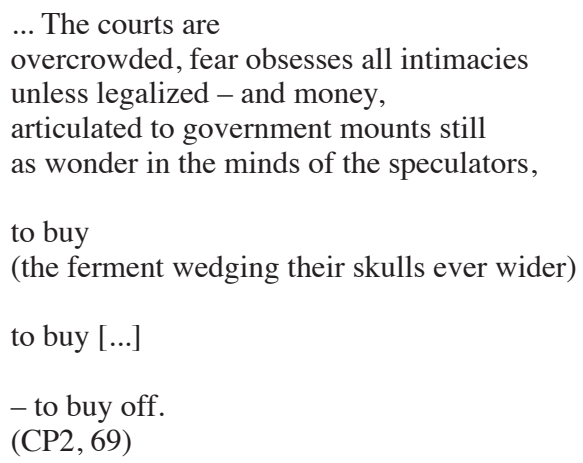

When viewed against such a spectacle of materialism and venality, indeed, "Election Day" may be seen to contain an inside joke, whereby Williams wags the dog (in this case, a literal "spotted dog"), to distract attention from the political and social implications of the scene described. The result - quite deliberately on Williams's part - is the opposite. By virtue of its very marginality, the slow, permeating poverty of the old man's surroundings stands in a metonymic relation to American political society at large. 
Williams is also once again offering a comment on descriptive verse itself, highlighting the material conditions which even the most seemingly selfenclosed of poetic images implies, and sometimes seeks to disguise. As Williams writes to Kenneth Burke in the late 1940s, "[m]y whole intent, in my life, has been [to] find a basis (in poetry, in my case) for the actual" ( $S L$, 257). As Williams sees it, the creation and appreciation of poetry should not direct attention away from collective life, but rather constitute an active expression, and at times exposure, of it.

If perhaps in a more expository mode, Williams makes a similar argument - or at least, raises similar questions - in his piece, "The Forgotten City" (also published in 1944). The poem is an exercise in political selfaccounting, which also has a number of aesthetic implications. Set during a "hurricane", as Williams and his mother drive "from the country" home to Rutherford, the poem casts Williams's surrounding cityscape as being both poetically elusive and materially imposing. "Brown torrents" of rain, Williams writes,

gushed up through new sluices in the valley floor so that I had to take what road I could find bearing to the south and west, to get back to the city. I passed through extraordinary places, as vivid as any I ever saw where the storm had broken the barrier and let through a strange commonplace: Long deserted avenues with unrecognized names at the corners and drunken looking people with completely foreign manners. Monuments, institutions and in one place a large body of water.... (CP2, 86-7)

The topography described has all the compelling presence and easy contradiction of a dream, as Williams encounters "[1]ong deserted avenues" on which "drunken looking people" are nonetheless staggering, and indeed as he perceives an entire system of urban life where he had never thought to find one. Taking only "what road / I could find", Williams gains access to the "extraordinary" and "vivid" energy of what is quite literally the "commonplace" $(C P 2,87)$. 
The poem in some ways may be read as a riff on Robert Frost's "The Road Not Taken", albeit with a thoroughly Williams-esque concern to connect the individualism of his poetic discoveries to the communal environment of modern (suburban) America. Hence, Frost's piece demonstrates and implicitly derides the temptation to attain to truths by self-deception - to declare "I took the [road] less traveled by, / And that has made all the difference", despite the fact that the other road is "just as fair" and both paths, indeed, "equally lay" before him when he made this choice (Frost, 103). Williams, on the other hand, seems intent to expose poetic solipsism as itself a kind of delusion. In contrast to Frost's cunning sense of both the persuasiveness and the illogic of poetic conviction, in Williams's poem aesthetic meaning and political purpose alike exist only by and through other people. I "promised myself", Williams continues,

I would some day go back to study this
curious and industrious people who lived
in these apartments, at these sharp
corners and turns of intersecting avenues
with so little apparent communication
with an outside world. How did they get
cut off this way from representation in our
newspapers and other means of publicity
when so near the metropolis, so closely
surrounded by the familiar and the famous?
(CP2, 87)

Williams deliberately draws attention to the "newspapers and other means of publicity" that exclude the daily round - and the people who live by it - from fame and familiarity, in the same way that the old man is implicitly excluded from fanfare and presumed benefits of American democracy in "Election Day". The paradox of such a situation, of course, is that by denying the "industrious" (working) people of America their place on elitist grounds, the poetic and political establishments ensure that the lives they live do indeed take on an "extraordinary" power. As Williams memorably asserts elsewhere: to "speak, / euphemistically, of the anti-poetic" is "Garbage", for it leaves "[h] alf the world ignored" - a circumstance which Williams is intent on rectifying here $(C P 2,68)$.

If Williams in the poems above highlights the creative significance of the lived experience of overlooked American communities in a semi-allegorical mode, he also frequently clarifies this insight further by depicting the 
literal scenes and people of his own surroundings. His poem, "A Portrait of the Times", sheds all elements of dreamscape evoked in "The Forgotten City", and roots the scene described in a New Jersey town. "Two W. P. A. Men", the poem reads,

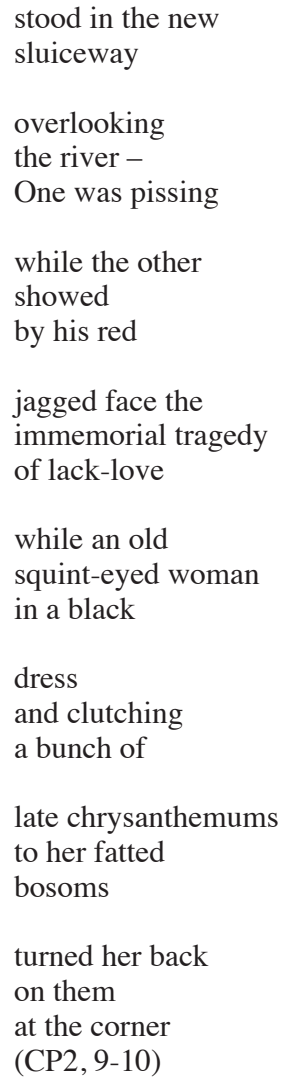

The snapshot of the two men and the wincing woman celebrates (and also ironizes) the installation of a local drainage system in light of its human process - and in this way chimes with Williams's association of poetic meaning with the capacity to record precisely the contours and tenor of one's material environment. Importantly, of course, the representativeness of the poem's situation as such - that which makes it "A Portrait of the Times" - stems primarily from the fact that the men are employed by the 
"W. P. A.", or the Works Progress Administration: one among a number of far-reaching New Deal programs providing paid work to exactly that class of citizens whose privations Williams portrays so often and so vividly, the proletarians, who appear in his earlier poetry especially as both dignified muses and (somewhat unwitting) emblems of modern American life. As before, the actual success of the W. P. A. in generating economic prosperity and alleviating social hardships has been questioned by a number of historians and political commentators. As William Appleman Williams succinctly observes:

The New Deal saved the system. It did not change it... the main efforts of relief, rationalization, and reform actually occurred in a jumble rather than proceeding in any stepby-step order or neat plan of development. Pragmatic to the core, the New Deal was not so much misdirected as it was undirected. (Contours, 434-40)

One result of this modus operandi of the New Deal, as we have seen, is the social bankruptcy and soaring levels of unemployment identified by Harry Hopkins in 1941. In the poem above, however, Williams himself casts the effectiveness of the W. P. A. scheme in doubt, focusing on the slapstick element of the labor involved, as well as on the "jagged" and "immemorial tragedy" of the worker's face - a guarded, but perspicacious retort to the supposed progress signaled by the Roosevelt administration's labor reforms.

In this respect, the piece arguably merits comparison with Robert Frost's famous (and famously critical) New Deal-era poem, "Two Tramps in Mud Time" (1934). In the latter, the Frost-persona questions whether he should offer his wood-chopping work to two men who had been "sleeping God knows where last night, / But not long since in the lumber camps" - and ultimately rules against such a course of action, declaring that although "I had no right to play / With what was another man's work for gain", his own situation, in which "love and need are one", grants him more of a moral claim to the labor than the "two hulking tramps" (Frost, 252). Artful as it is, the poem in effect gives literary life to Frost's abiding complaint at the time, that "the lower classes" are now "to be completely taken care of by the upper classes", as he writes in 1939 (Frost, 778). As George Monteiro notes: "Two Tramps" records Frost's skepticism towards "the basic premise of practicing social welfare", particularly when this comes at the supposed detriment "of an individual's right to well-being" - Frost's meditation on 
physical (and personal) labor in a time of general poverty founded on a dichotomy of "the needs of spirit, aspiration, and self-fulfillment against the need for working for food" (Cambridge Companion to Robert Frost, 223-24). Frosts's rankled opposition to "working for food" may of course help to contextualize Williams's view of the older poet "as a reactionary with 'no grasp of the crucial issues' facing his world", particularly when compared to Williams's own sensitivity to questions (and facts) of deprivation throughout his life (Mariani, 638). In any case, Frost's poem in turn clarifies Williams's approach in "A Portrait of the Times", which draws into the critical spotlight not the premise of social welfare, but the effectiveness of those programs already implemented - as well as the physical wellbeing and embodied humanity of the various actors described.

It is worth noting the remarkable extent to which the poem's political commentary (implicit or otherwise) is an effect once again of its exploratory visual practice - thus standing as another of Williams's parabolic, if precisely observed social descriptions. Williams's "Portrait of the Times" seems almost fixated with forms of seeing and impediments to sight - both internal to the scene described and relating to Williams's own creative-spectatorial role. The two men are "overlooking / the river", although in opposite directions: one, towards the water into which he is "pissing", and the other, presumably, towards Williams himself, who consequently perceives his face with such clarity. The old woman, similarly, is "squint-eyed" and actively reluctant to observe the scene, turning her back on the W. P. A. workers "at the corner" $(C P 2,10)$. Williams's own role, finally, is all-seeing and artistically integral, and yet seems curiously constricted, lacking (in this instance) the motion and agency which the other figures clearly possess.

If the poem presents a political vision of its place and era, it does so largely by demonstrating both the necessity and the various limitations of visual perception as such. As discussed above, the foregrounding of both conflicting visibilities and perceptual disjunctions is a notable feature of Williams's work in this period, and indeed is symptomatic of the significance he accords to the politics of materiality in his poems in general. His late piece, "A Vision of Labor: 1931" (1940), thus develops and focuses the concerns of the poem above, while also partially revising Robert Browning's "The Bishop Orders his Tomb at Saint Praxed's Church" (substituting the pontiff's dying vision, as the title suggests, with a close-focus scan and perspective of the latter-day "ditch diggers" themselves). "In my head", Williams writes, this time as a self-conscious artist-spectator, 
... the juxtapositions

impossible otherwise to accomplish:

two young rubber-booted ditchdiggers

beside the bed of the dying bishop -

cracking obscene jokes...

$(\mathrm{CP} 2,81)$

As in "A Portrait of the Times", the two workers seem unaware of being watched, while also standing as active observing agents in the scene depicted: "washing their / hip-boots off in the stream jerking / from the pump at the finished manhole", they stare distracted at a "girl lying there / supine in [an] old rowboat" nearby, "looking down and smiling over / her like insane men" $(C P 2,81-2)$. The uneasy sexual dynamic between the three figures of course is predicated on the sexist reduction of the girl to a product of the men's desires. So she lies "flat out there in the heat with / her five-and-ten dark glasses on", while her "white suit", Williams writes, is "pulled up tight into her crotch" $(C P 2,82)$. Critically perturbing as such objectifications are, we should note Williams's method here: whereby he becomes doubly the voyeur, adapting the viewpoint and observational focus of the two workers he himself surveys (in contrast to Browning's piece above).

Importantly, Williams seems not entirely heedless of the sexual transgressiveness to which the politics of visuality here gives license. The poem after all contains the interjection, that

[w] hen you've been broke and damned near starving for five years you get to look that way...

and so acknowledges (if also, to an extent, explains away) the predatory spectation of the two men. It also highlights the prolonged material and physical deprivation which, as working class citizens, Williams presumes they have endured. "You can't help it", the poem continues, "That's / poverty. Both your mind and your body / are affected" $(C P 2,82)$.

There is, needless to say, an unsettling bias in Williams's ascription of sexual voracity to these figures on the basis of their working-class identity - in the connection he posits, that is, between poverty, on the one hand, and mental and physical perversion on the other. In this respect, the poem perhaps illustrates some of the deficiencies of Williams's worldview and 
aesthetic approach, concisely indicating what seems to be a reflexive recourse to reductive classifications as a means of understanding workingclass people and living conditions in particular. It is on such a score, indeed, that Bob Johnson can accuse Williams of a "pure aestheticization of the oppressed" in his work - a critically suggestive conclusion, which is arguably tempered, however (and as we have seen elsewhere in this discussion) by the consistent anti-establishmentarianism and politically sensitive portraiture to be found throughout his poetry (Johnson, 203). Williams often refuses such aestheticization, in brief, with the same intensity with which he apparently indulges in it elsewhere.

If Williams's later poems both expose and reiterate the prejudicial discourses, concerns, and frames of understanding that permeate his society, their distinctive and abiding value may ultimately lie in the "brilliant / colors of the chronicler" they display $(C P 2,387)$. Ranging from erratic rants to delicately seething snapshots of his locale, from his imagination of war abroad to the glimpsed and held reality of sickness, hardship and otherwise anonymous lives at home, Williams's chronicle makes of poetry "[a]n ungainly flower / and an unnatural one" $(C P 2,258)$, which nonetheless fits "in distressing / detail" the world he knows $(C P 2,27)$. In this way, Williams's work sets out to effect - if not political change per se, then communication in a new mode, which for Williams is perhaps the deeper necessity. To the question, "How shall we get said what must be said?", Williams can thus reply, "Only the poem": the site of first and final understanding, where the reality of suffering and the possibility of beauty each hold equal place, and the ecstasies of life may be generally shared $(C P 2,160)$. 


\section{Works Cited}

Cohen, Milton A., MacGowan, Christopher, ed., "Williams and politics", The Cambridge Companion to William Carlos Williams (Cambridge: Cambridge University Press; 2016).

Copestake, Ian, The Ethics of Williams Carlos Williams's Poetry (New York: Camden House, 2010).

Frost, Robert, Poirier, Richard, Richardson, Mark, Collected Poems, Prose, and Plays (New York: Library of America; 1995).

Forrest, Seth, “'The mind / is listening': Aurality and Noise Poetics in the Poetry of William Carlos Williams", William Carlos Williams Review (Vol. 33, Nos 1-2; 2016).

Ginsberg, Allen, Deliberate Prose (New York: Harper Collins; 2000).

Greenberg, Clement, MacDonald, Dwight, "10 Propositions on the War", Partisan Review (July- August, 1941).

Heffernan, Michael, Coghill, Sheila, Tammaro, Thom, eds., “An Exculpation”, Visiting Dr. Williams (Iowa: University of Iowa Press; 2011).

Johnson, Bob, “'A Whole Synthesis of His Time': Political Ideology and Cultural Politics in the Writings of William Carlos Williams, 1929-1939”, American Quarterly (Vol. 54, Issue $2 ; 2002$ ).

Käck, Elin, "Linguistic Transformation as Counter-Hegemonic Operation in Kora in Hell and Spring and All", William Carlos Williams Review, (Vol. 33, Nos. 1-2; 2016).

Mariani, Paul, William Carlos Williams: A New World Naked (San Antonio: Trinity University Press; 1981).

Marsh, Alec, "William Carlos Williams and the prose of pure experience", ed., MacGowan, Christopher, Cambridge Companion to William Carlos Williams (Cambridge: Cambridge University Press; 2016).

Matterson, Stephen, Davis, Alex, Jenkins, Lee, eds., "American Modernism from the 1930s to the 1950s: Williams and Stevens to Black Mountain and The Beats", A History of Modernist Poetry (Cambridge: Cambridge University Press; 2015).

Monteiro, George, Faggen, Robert, ed., "Frost's Politics and the Cold War", The Cambridge Companion to Robert Frost (Cambridge: Cambridge University Press; 2001).

Reuters, "Bombs Wreck Commons Chamber, Unroof Abbey, Hit British Museum...", The New York Times (12 May, 1941).

Roediger, David, How Race Survived US History: from Settlement and Slavery to the Obama Phenomenon (New York: Verso; 2008).

Williams, William Appleman, The Contours of American History (New York: Verso; 2011/1961).

Williams, William Carlos, Litz, Walton A., MacGowan, Christopher, eds., Collected Poems: Volume 1 (1909-1939) (New York: New Directions; 2000/1991).

. MacGowan, Christopher, ed., Collected Poems: Volume 2 (1939-1962) (New York: New Directions; 2000/1991).

MacGowan, ed., Paterson (New York: New Directions; 1995/1992).

Wintemeyer, Hugh, ed., William Carlos Williams \& James Laughlin: Selected Letters (New York: New Directions; 1989).

Wordsworth, William, Gill, Stephen, ed., A William Wordsworth Reader (Oxford: Oxford University Press; 2010).

Zinn, Howard, A People's History of the United States (London: Harper; 2003/1980). 